\title{
Work Engagement and Voluntary Absence: The Moderating Role of Job Resources
}

\begin{abstract}
The present study examined the moderating role of job resources, namely, organisational trust, the quality of employees' relationship with their manager, and the motivating potential of jobs, on the negative relationship between work engagement and voluntary absence. Employee survey results and absence records collected from the Human Resources Department of a construction and consultancy organisation in the United Kingdom $(n=325)$ showed that work engagement was negatively related to voluntary absence, as measured by the Bradford Factor. Further, the results showed that organisational trust and the quality of employees' relationships with their line managers ameliorated the negative effect of relatively low levels of engagement on voluntary absence. Theoretical and practical implications of the findings are discussed.
\end{abstract}




\section{Work Engagement and Voluntary Absence: The Moderating Role of Job Resources}

Research has produced staggering estimates of the cost of employee absenteeism to organisations. For instance, the cost of absence amounts to $12.1 \%$ of total annual payroll expenses in Canada (Towers Watson, 2012), \$74 billion annually in the United States (Conlin, 2007), and approximately $£ 600$ per employee each year in the United Kingdom (CIPD, 2010). Aside from the direct cost implications of employee absenteeism for organisations, it also has indirect costs. For instance, absent employees may jeopardise the completion of a project, miss out on opportunities with clients or customers, and/or detract from the effectiveness of others at work (Sagie, Birati, \& Tziner, 2002).

Although research has identified that a potential antidote to absence is work engagement (e.g., Schaufeli, Bakker, \& Van Rhenen, 2009; Soane, Shantz, Alfes, Truss, Rees, \& Gatenby, 2013), no research, to our knowledge, has analysed factors that may influence this relationship. The main contribution of the present study lays in the building of theoretical arguments, and an empirical examination of job resources that moderate the relationship between engagement and absence. Specifically, we argue that work engagement and job resources produce a multiplicative effect such that when employees experience high levels of both, employee absenteeism is lowest. For employees who are relatively disengaged, we argue that job resources buffer the negative effect of low levels of engagement on absence. In other words, when engagement is relatively low, job resources may produce a compensatory effect, causing absence levels to be lower than if engagement and the job resource were both absent.

\section{Absenteeism}

Although absence is a complex phenomenon involving the interplay among societal, workplace, and personal factors (e.g., Dekkers-Sánchez, Hoving, Sluiter, \& Frings-Dresen, 2008), absence can be classified as either involuntary or voluntary. In other words, employees 
are absent because they are either unable (involuntary absence) or unwilling (voluntary absence) to attend work (e.g., Chadwick-Jones, Nicholson \& Brown, 1982; Johns, 1997; Schaufeli et al., 2009).

In most studies, voluntary absence is measured as absence frequency (i.e. the number of absence episodes) and involuntary absence is measured as absence duration (i.e. the number of days absent). Although some research finds support for this dichotomy (e.g., ChadwickJones et al., 1982; Bakker, Demerouti, de Boer, \& Schaufeli, 2003; Schaufeli et al., 2009), researchers' agreement about the measurement of voluntary absence is not unanimous; some argue that equating absence frequency with voluntary absence is artificial and misleading (e.g., Farrell \& Stamm, 1988; Steel, 2003; Shapira-Lishchinsky \& Rosenblatt, 2009; ten Brummelhuis ter Hoeven, de Jong and Peper, 2013). Moreover, the results of meta-analyses (Farrell \& Stamm, 1988; Hackett \& Guion, 1985; Scott \& Taylor, 1985) do not provide a strong case for treating absence frequency as a measure of voluntary absenteeism.

Some scholars have suggested that measures of absence duration and frequency are intertwined (Harvey \& Nicholson, 1999; ten Brummelhuis et al., 2013) and that rather than forming two distinct categories, the duration/frequency typology represents a continuum of degrees of voluntary employee absence (Brooke, 1986). Hence, it is more useful to use a measure of voluntary absence that emphasises frequency of absence, but also incorporates its duration.

In the present study, we used the Bradford Factor because it takes into consideration both the number of incidences and the duration of each incident to compute an absence score for each employee. In other words, the Bradford Factor measures an employee's irregularity of attendance and is calculated as (number of absence episodes) $)^{2} \mathrm{x}$ number of days absent. For example, one absence episode of ten days in duration equals ten points; ten absence episodes of one day each equals 1000 points. This formula emphasises the frequency with which 
absence spells occur, but it does not ignore the duration of the absence episodes. Hence, it allows a more holistic snapshot of an individual's absenteeism and is therefore a suitable way to capture voluntary absence caused by a lack of motivation (Taylor, 2008).

Absenteeism and Work Engagement. Employee engagement is a promising antecedent of voluntary workplace attendance because it is central to an energetic and motivational work-related process (e.g., Bakker \& Demerouti, 2007). Engagement is defined as a "positive, fulfilling work-related state of mind characterised by vigor, dedication and absorption” (Schaufeli, Salanova, Gonzalez-Roma, \& Bakker, 2002, p. 20). Engaged employees exert a high level of energy and persist in the face of difficulties (vigor); they are highly involved in work and thereby experience a sense of pride and enthusiasm for it (dedication); and they are fully focused on work so that time appears to pass by quickly (absorption).

Engagement is likely to be inversely related to absenteeism for a number of reasons. First, Johns (1997) argued that voluntary, as opposed to involuntary absence, is best explained by models that focus on psychological job attitudes, such as engagement. Second, engaged employees are self-determined to accomplish tasks despite perceived obstacles. In the face of setbacks at work, engaged employees are less likely to be voluntarily absent, and instead they relish in challenges presented to them at work. Third, engaged employees find their work stimulating, which draws them to spend more time at work. Finally, being engrossed in one's work also contributes to lower voluntary absence rates, as employees who are fully absorbed in work experience flow, that is, they find their work intrinsically enjoyable and difficult to detach from (Csikszentmihalyi, 1990).

Three published studies, to our knowledge, have examined the relationship between engagement and absence. The results revealed that engagement is negatively related to company-registered number of absence days (absence duration) for support service workers in 
the United Kingdom (Soane et al., 2013), self-report absence days (absence duration) of coworkers of a Dutch police organisation (ten Brummelhuis et al., 2010), and the number of company-registered absence episodes (absence frequency) and absence days (absence duration) of telecom managers in the Netherlands (Schaufeli et al., 2009). In the present study, we test the hypothesis that engagement is inversely related to company-registered absence using the Bradford Factor to compute voluntary absence:

Hypothesis 1: Engagement is negatively related to voluntary absence.

\section{Job Resources}

Job resources refer to physical, social or organisational aspects of the job that reduce the physiological or psychological costs of job demands, are functional in achieving work goals, and/or stimulate personal growth and learning (Bakker \& Demerouti, 2007; Demerouti, Nachreiner, Baker, \& Schaufeli, 2001). Resources are important in their own right (Hackman $\&$ Oldham, 1975, 1976) and also as a means to achieve and protect other valued resources (Hobfoll, 1989). In the present study, we examine organisational trust (an organisation-level resource), employees' relationships with their leader (an interpersonal-level resource), and the motivating potential of jobs (a task-level resource) as job resources (Bakker \& Demerouti, 2007).

These three job resources were chosen for two reasons. First, they have theoretical and empirical ties with absenteeism (e.g., Colquitt, Scott \& LePine, 2007; Fried \& Ferris, 1987; van Dierendonck, Le Blanc, van Breukelen, 2002). Second, Kahn (1990) suggested that elements of one's work environment, such as organisational trust, leadership, and task characteristics, are relevant in understanding how engagement unfolds at work. He implied that features of the work environment set boundaries on the extent to which engagement is likely to be fully expressed at work. Specifically, he stated that when work situations are clear, consistent and predictable (i.e. high levels of organisational trust), when management is 
supportive and clarifying (e.g., high quality manager-employee relationships), and when work tasks are organised such that employees have autonomy and variety in their work (e.g., high levels of motivational job design), employees feel safe and able to fully express their engagement at work.

Organisational Trust. Organisational trust refers to employee perceptions of the employer's integrity, motives, openness and behavioural consistency (Dirks \& Ferrin, 2001; Robinson \& Rousseau, 1994). Organisational trust, as a job resource, is functional in achieving work goals, because it increases an employee's willingness to take risks and increases employees' identification with the organisation (Edwards \& Cable, 2009). Trust in the organisation also encourages employees to share knowledge amongst each other (McEvily, Perrone, \& Zaheer, 2003), thereby stimulating personal growth and learning.

Leadership. Leader-member exchange (LMX) refers to the quality of the relationship between a subordinate and leader. A high quality LMX relationship is characterised by reciprocal trust, respect, and the expectation of a future positive relationship, whereas a low quality relationship is characterised by just the opposite; it is based solely on the fulfillment of the employment contract (Graen \& Uhl-Bien, 1995). Employees in high quality relationships receive increased communication, better roles, have higher levels of emotional support and greater access to organisational resources, compared to those in lower quality LMX relationships (Dienesch \& Liden, 1986; Graen \& Scandura, 1987; Wayne, Shore \& Liden, 1997). Hence, a high quality LMX relationship is a job resource because it helps employees achieve important work goals, provides a support mechanism to defend against job demands, and spurs employee development.

Job Design. The third moderator under consideration is the motivating potential of jobs. Hackman and Oldham (1975) proposed that five job characteristics have the potential to intrinsically motivate employees: task variety, task identity, task significance, autonomy, and 
feedback from the job. An overall motivating potential score (MPS) is typically calculated from the core job dimensions. That MPS is considered a job resource is consistent with Hackman and Oldham's (1980) contention that task characteristics are motivational, assist in achieving work goals, and facilitate jobholders' learning and development.

\section{The Moderating Role of Job Resources}

Research has shown that both engagement and job resources are negatively related to absenteeism (e.g., Bakker et al., 2003; Schaufeli et al., 2009; Soane et al., 2013). Despite this, the two variables have seldom been considered concomitantly in a study on absenteeism. In fact, only one study has simultaneously examined engagement and job resources on absenteeism. Schaufeli et al. (2009) found that increases in job resources predicted work engagement, and engagement was negatively related to absence duration and frequency. This study, however, did not consider an interaction between engagement and job resources on absenteeism. Although job resources have typically been studied as antecedents of work engagement (e.g., Bakker \& Demerouti, 2007), an influential review of the absence literature suggested that absence is likely most strongly influenced by combinations (interactions) of variables (Johns, 1997). Ignoring the potential interaction between engagement and job resources on absence may be limiting, since there are good conceptual reasons to posit that an interaction might take place.

There are at least three theoretical frameworks that support the contention that absence is lowest for those who are highly engaged and have access to job resources. First, conservation of resources (COR; e.g., Hobfoll, 1999, 2011) theory suggests that organisational trust, LMX, and MPS are job resources. Gorgievski-Duijvesteijn and Hobfoll (2008) added that engagement is an "intrinsic energetic resource" and that resources operate synergistically to produce in employees an even greater ability to overcome obstacles, perform at higher levels, and maintain a healthy sense of wellbeing. They theorised that there 
is a potential for an interaction (i.e. moderation) between individual resources, such as engagement, and job resources.

Second, according to Broaden and Build Theory (Fredrickson, 1998, 2001), a positive state such as work engagement has the capacity to broaden an individual's momentary thought-action repertoire through expanding the obtainable array of potential thoughts and action that come to mind (Fredrickson \& Branigan, 2001; Wright, 2005). Experiencing the positivity generated from work engagement may lead individuals to thrive and flourish. Additional resources may strengthen this effect (Fredrickson, 1998, 2001). In other words, Fredrickson's model suggests that engagement may interact with job resources because of their complementary broadening (engagement) and building (job resources) effects.

Third, Blumberg and Pringle (1982) argued that in order to understand employee behaviour, it is not only necessary to examine employees' ability and motivation, but also the opportunity that they have to invest themselves in their work. Employees have an opportunity to invest themselves in work if they have adequate resources (e.g., high trust in the organisation, high quality LMX relationship, and an enriched job). Importantly in the present discussion, they stressed that motivation (i.e., engagement) and opportunity (i.e. job resources) are not only additive, but they also interact, such that those with the highest motivation and the most opportunity are most likely to achieve the highest level of performance. In the same way, employees who are engaged are less absent in their role when they are provided with a resource-laden environment (e.g., high trust in their organisation, high quality LMX relationship, and enriched jobs). Taken together, these three theoretical models imply that job resources and engagement produce a synergistic effect, such that absence is lowest when both are high.

Job resources may not only strengthen the negative relationship between engagement and absence for highly engaged employees; research on the buffering hypothesis (Caplan, 
1974) suggests that job resources may also play a buffering role for those who are relatively disengaged at work. The theory was originally developed to explain the effect of social support on the outcomes of stress. It stipulates that support can ameliorate the deleterious effects of stress on individuals' health and wellbeing, and that support has little impact on individuals who are not stressed. Cohen and McKay (1984) elaborated upon the buffering hypothesis in positing that resources can buffer the negative consequences of stress if the resources either provide the person with tangible tools to overcome the stress, if they assist in cognitive re-appraisal of the situation, and/or if they provide the person with positive feedback or a sense of belonging.

The buffering hypothesis (Caplan, 1974) and empirical evidence supporting it (e.g., Miner, Settles, Pratt-Hyatt \& Brady, 2012) provide theoretical support for the interaction between engagement and job resources specifically at low levels of engagement. Research on the buffering role of job resources on engagement (Bakker, Hakanen, Demerouti \& Xanthopoulou, 2007), burnout (Xanthopoulou et al., 2007), and absence frequency (Demerouti, Bouwman, \& Sanz-Vergel, 2011) likewise support the hypothesis that job resources play a buffering role. Hence, employees with low level of engagement may nevertheless have higher levels of attendance if they are provided with adequate job resources.

Hypothesis 2: Organisational trust moderates the negative relationship between engagement and voluntary absence.

Hypothesis 3: A high quality LMX relationship moderates the negative relationship between engagement and voluntary absence.

Hypothesis 4: High levels of MPS (motivating potential score) of jobs moderates the negative relationship between engagement and voluntary absence. 


\section{Methods}

\section{Participants}

The data for this study was sourced from a construction and consultancy organisation in the United Kingdom. The organisation offers integrated services across the property and infrastructure life cycle. Their work involves project management, construction delivery and facilities management across a number of sectors including arts and culture, education, energy and utilities, hotels and sport, science and technology, and transport. The organisation has a relatively large Human Resource (HR) Department, which serves as an advisor on Human Resource Management (HRM) issues to line managers. They also liaise between employees and line management.

Within the HRM department, there is an Absence Partner who takes calls from absent employees and reports them to the absent employee's line manager and project coordinator. The Occupational Health Advisor periodically reviews absence information and follows up with employees who are frequently absent via telephone calls. Notwithstanding these efforts, employee absence has been a growing concern for the HR Director of the organisation, as absence rates have steadily increased from approximately 2.5 days per employee per year in 2007 to 5.2 days per employee per year in 2012. The HR Director acknowledged that although there is little she can do to remedy involuntary absenteeism (e.g., sickness), she is interested in finding ways to reduce voluntary absenteeism. Hence the current study was of particular interest to this organisation.

Electronic surveys were sent to 671 employees of this organisation. The respondents were encouraged to participate in the survey within two weeks. All employees were given time to complete the survey at work. Employees were informed of the purpose of the data collection (i.e., to gather opinions of their work) and its confidentiality. Four hundred and fourteen surveys were completed. Eighty-nine respondents were excluded due to incomplete 
absence data. These employees worked in overseas offices where absence data is not collected by the HR department. Hence, the response rate was $48 \%$.

Of the 325 remaining participants, $60.6 \%$ were male; the mean age of participants was $40.12(S D=11.55)$; the proportion of married individuals was $46 \%$. Approximately $54 \%$ of the sample had a university degree or above, 10\% had other higher (e.g., college) education, 12\% had A-levels (pre-university/college credits) or equivalent, 15\% had GCSE (high school diploma) or equivalent, 7\% had other job-related qualifications (e.g., UK National Vocational Qualifications include job-related sector courses, such as Basic Plumbing Studies or Business Administration), and 2\% had no qualifications. Approximately $35 \%$ of the respondents were engineering and construction professionals, $20 \%$ held administrative roles, $24 \%$ were managers, $5 \%$ held customer service roles, $2 \%$ were general laborers, and the remaining employees indicated 'other type of work'. Tests were conducted to determine whether there were significant differences between the 89 excluded employees (due to missing absence data) and 325 included employees in terms of gender, age, marital status, type of work, and education level. All tests were not significant. Absence records were obtained from the HR department four months subsequent to the completion of the survey.

\section{Measures}

Scale reliabilities are found in Table 1 . All items for all scales were scored on a 1 (strongly disagree) to 7 (strongly agree) scale, unless otherwise noted.

Engagement. Engagement was measured using Schaufeli et al.’s (2003) self-report questionnaire consisting of seventeen items, which capture the three dimensions of engagement, namely, vigor (e.g., When I get up in the morning, I feel like going to work), dedication (e.g., I am enthusiastic about my job), and absorption (e.g., Time flies when I am working). The items were scored on a 1 (never) to 7 (always) scale. A mean score was calculated from the three components to reflect an overall measure of engagement. 
Organisational Trust. Robinson and Rousseau's (1994) scale captures the extent to which employees trust their organisation (e.g., I believe my employer has high integrity).

Leadership. The quality of the relationship with one's leader was measured using the LMX scale developed by Graen, and Uhl-Bien (1995; e.g., My working relationship with my leader is effective).

Job Design. Job design was operationalised as a motivating potential score (MPS). The MPS was calculated by taking the average of five job characteristics using scales developed by Morgeson and Humphrey (2006), namely, decision-making autonomy (3 items; e.g., The job provides me with significant autonomy in making decisions), task variety (4 items; e.g., The job requires the performance of a wide range of tasks), task significance (4 items; e.g., The job itself is very significant and important in the broader scheme of things), task identity (e.g., 4 items; The job is arranged so that I can do an entire piece of work from beginning to end), and feedback from the job (3 items; e.g., The job itself provides feedback on my performance).

Voluntary Absence. The number of recorded absence episodes and duration over four months subsequent to the completion of the survey were collected from organisational records. Each participant was assigned a Bradford Factor score calculated as (number of absence episodes $)^{2} \mathrm{x}$ number of days absent.

Control variables. Age, gender (female=1), and whether an employee managed others (manages others $=1$ ) were used as control variables in all analyses, because metaanalyses suggest that they are related to absence (e.g., Darr \& Johns, 2008; Martocchio, 1989). All of the analyses presented below were conducted twice, once with and once without control variables. The results were consistent across the analyses (Becker, 2005). Hence, we are confident that the inclusion of the control variables did not alter our main findings. The results below present the analyses that include the control variables. 


\section{Results}

\section{Descriptive Statistics and Preliminary Analyses}

SPSS (version 21) was used to calculate the descriptive statistics and to test the hypotheses. Table 1 presents the scale reliabilities, means, standard deviations, and correlations amongst the variables.

Insert Table 1 about here

Tests of Discriminant Validity. As the measures for engagement, organisational trust, leadership and job design were collected at one point of time, a series of confirmatory factor analyses were carried out in AMOS (version 21) to assess the discriminant validity of the measures. A full measurement model was initially tested, in which the three facets of engagement loaded onto a general engagement factor, the five facets of job design loaded onto a general MPS factor and all indicators for organisational trust and leadership were allowed to load onto their respective factors. All factors were allowed to correlate. Five fit indices were calculated to determine how the model fitted the data (Hair, Black, Babin, \& Anderson, 2009). For the $X^{2} / \mathrm{df}$ values less than 2.5 indicate a good fit and values around 5.0 an acceptable fit (Arbuckle, 2006). For the Comparative Fit Index (CFI) and Tucker-Lewis coefficient (TLI) values above .90 are recommended as an indication of good model fit (Bentler, 1990; Bentler \& Bonett, 1980). For the Root Mean Square Error of Approximation (RMSEA) and Standardised Root Mean Square Residual (SRMR) values less than .06 indicate a good model fit and values less than .08 an acceptable fit (Browne \& Cudeck, 1993; Hu \& Bentler, 1998). The four-factor model showed a good model fit $\left(X^{2}=592 ; \mathrm{df}=202\right.$; $\mathrm{CFI}=.93 ; \mathrm{TLI}=.92 ; \mathrm{RMSEA}=.077 ; \mathrm{SRMR}=.055)$. All factor loadings were above the suggested threshold of .5 (between .63 and .95) and significant at the $\mathrm{p}<.001$ level. Next, sequential $X^{2}$ difference tests were carried out. Specifically, the full measurement model was compared to six alternative nested models, as shown in Table 2. Three models (A, B, C) were 
created to assess the distinctiveness of the independent variable from each moderator variable. Model D was created to assess the distinctiveness of trust and LMX, given the possibility that employee ratings of these constructs are affected by halo error, such that employees who provide a high rating to their leader may also provide a high rating to their organisation because they view their leader as an agent of the organisation. Model E was created to assess whether the three different job resources were distinct. Finally, a single-factor model was tested (Model F). Results of the measurement model comparison revealed that the model fit of the alternative models was significantly worse compared to the full measurement model (all at $p<.001)$. This suggests that the variables in this study are distinct.

Insert Table 2 about here

Moreover, we carried out a number of tests to ensure that each hierarchical moderated regression model met the assumptions of regression (Field, 2013; Stevens, 2002). Relevant test statistics are available by request from the first author.

\section{Hypothesis Testing}

Hypothesis 1 predicted that engagement is negatively related to absence. The results of a multiple regression analysis indicated that the model was significant $(F=2.76, p<.05$, $R^{2}=.04$ ) and after controlling for age, gender and managerial role, engagement was significantly and negatively related to absence $(\beta=-.21, S E=.36, t=-3.22, p<.01)$. Hypothesis 1 was supported.

Hierarchical moderated regressions were used to test the remaining hypotheses. Variables entered into moderated regressions were standardised (Aiken \& West, 1991). Table 3 presents the results. In the first column, labeled Baseline Model, absence was regressed on gender, age and managerial role only. In the column labeled Moderating Role of Organisational Trust, the first sub-column shows the results of the main effect model (controls, engagement and organisational trust) and the second sub-column shows the 
moderated regression model (controls, engagement, organisational trust and the interaction between engagement and organisational trust) on absenteeism. The columns that represent the moderating role of leadership (LMX) and job design (MPS) are similarly presented.

The second hypothesis predicted that organisational trust would moderate the relationship between engagement and absence. The interaction between engagement and trust was significant (column 3 of Table 3). The relationship is plotted in Figure 1.

Insert Table 3 and Figure 1 about here

Figure 1 reveals that employees with relatively low levels of both trust and engagement showed the highest level of voluntary absence. Simple slope analyses indicated that at relatively low levels of organisational trust, engagement was negatively related to absence $(\beta=-.25, S E=.36, t=-3.16, p<.05)$, whereas at relatively high levels of organisational trust, engagement was not related to absence $(\beta=-.03, S E=.41, t=-.29, p=$ n.s. $)$. Hypothesis 2 was partially supported.

We also examined whether the endpoints of trust at high versus low levels of engagement (see Figure 1) were different from one another. To do so, we swapped the independent variable (engagement) and moderator (trust) and conducted an additional simple slopes test (Dawson, in press). The results showed that the slope of the line at high levels of engagement was not significantly different from zero $(\beta=-.49, S E=.40, t=.23, p=$ n.s. $)$ whereas the slope of the line for those with lower levels of engagement was negative and significantly different from zero $(\beta=-.88, S E=.33, t=-2.66, p<.01)$. This implies that the two points on Figure 1 at lower levels of engagement are significantly different from one another. Hence, trust makes a difference at lower levels of engagement.

The second hypothesis predicted that the quality of the relationship employees have with their leader moderates the negative relationship between engagement and absence. 
Column 5 of Table 3 presents the results of this hierarchical moderated regression. The interaction term was positive and significant. The relationship is plotted in Figure 2.

Insert Figure 2 about here

Simple slope analyses indicated that at relatively lower quality LMX relationships, engagement was negatively related to absence $(\beta=-.33, S E=.39, t=-3.91, p<.05)$, whereas when employees had relatively higher quality LMX relationships, engagement was not related to absence $(\beta=-.04, S E=.39, t=-.42, p=$ n.s. $)$.

To examine whether there is a significant difference between the endpoints of LMX at high levels of engagement (see Figure 2), we swapped the independent variable (engagement) and moderator (LMX) and conducted an additional simple slopes test (Dawson, in press). The results showed that at lower levels of engagement, the slope of the line is significantly different from zero $(\beta=-.81, \mathrm{SE}=.34, t=-2.38, p<.05)$. Conversely, the negative relationship between LMX and absence was not significant at high levels of engagement $(\beta=-.49, S E=.39$, $t=1.27, p=$ n.s.). This suggests that the two points at the far side of Figure 2 are not significantly different from one another. Hypothesis 3 was partially supported.

The fourth hypothesis predicted that perceptions of job design would moderate the negative relationship between engagement and absence (see Column 7 of Table 3 ). The interaction term was positive and significant.

Insert Figure 3 about here

Simple slope analyses indicated that for employees who reported that their jobs contain relatively low levels of motivating potential, engagement was negatively related to absence $(\beta=-.40, S E=.40, t=-4.62, p<.05)$ whereas for those who report relatively high levels of motivating potential in their jobs, engagement was not related to absence $(\beta=-.06, S E=. .41$, $t=-.54, p=$ n.s.). 
To investigate whether the endpoints of MPS at high and low levels of engagement are significantly different from one another (see Figure 3), we swapped the independent (engagement) and moderator (MPS score) and conducted a second simple slopes test (Dawson, in press). The negative relationship between MPS and absence was significantly different from zero for employees with relatively higher levels of engagement $(\beta=.99, S E=.45$, $t=-2.18 p<.05)$, but not at lower levels of engagement $(\beta=-.25, \mathrm{SE}=.35, t=-.72 p=\mathrm{n} . \mathrm{s}$. $)$. This implies that the end points that represent employees at high levels of engagement and high versus low levels of MPS are significantly different from one another. In summary, although there was a significant interaction between engagement and MPS, the additional analyses suggest that high levels of MPS do not influence the relationship between engagement and absence. This unanticipated finding is discussed below.

Additional test. In order to further validate our results, we tested each of our hypotheses using moderated structural equation modeling (MSEM; Cortina, Chen \& Dunlap, 2001; Mathieu, Tannenbaum, \& Salas, 1992; ten Brummelhuis et al. 2011). The MSEM results and resulting plots mirror those produced by our hierarchical moderated regression analyses. The details of the MSEM procedure and results are available by request from the first author.

\section{Discussion}

Although the buffering hypothesis (Caplan, 1974) was originally developed to explain the impact of support on the outcomes of stress, the theory and its associated empirical research show a striking similarity with the pattern of results found in this study, that is, at lower levels of engagement, organisational trust and LMX buffered the negative relationship between work engagement and voluntary absence. These findings caution against arguments that disengaged employees are necessarily a cost to organisations (Wollard, 2011). Indeed, the 
results of the present study show that work engagement and some job resources compensate for one another.

The results also showed that for relatively highly engaged employees, job resources did not enhance the negative relationship between engagement and absenteeism. These results come as a surprise given that there are theoretical arguments to suggest that the relationship between engagement and absence is strengthened by resources that help employees achieve work goals, to cope with work challenges, and to develop and grow.

A potential reason for the non-significant finding may be the positive correlation between work engagement and the three job resources; highly engaged employees are more likely to have more resources. A pressing question is whether this is an empirical or theoretical issue. Empirically, an interaction may not have surfaced because of the positive relationship between job resources and engagement. Hence, there may have been insufficient power to detect such an interaction, especially given that this study was conducted in the field (Morris, Sherman \& Mansfield, 1986). Additionally, there may be a threshold effect, or restriction of range. A highly engaged worker may not be intentionally absent from work at all, or to a very small extent, so that there is little room for a further decrease in voluntary absence (Sagie, 1998). McClelland and Judd (1993) stated that field studies are problematic because the distributions of the independent and dependent variables are commonly restricted by their respective ranges, which is exacerbated by the multiplication of the interaction term, reducing the power to detect an interaction. Post-hoc tests of our data confirmed that this might explain our results; the variance of absence was larger at lower levels compared to higher levels of engagement.

Theoretically, it may be that job resources do not interact with engagement at high levels to predict relevant outcomes, such as absence. Although Broaden and Build theory has been used to position engagement as a mediator of the relationship between job resources and 
outcomes, we used it to support an interaction between engagement and job resources. More theory building is needed to understand the condition(s), if any, under which high levels of engagement can be strengthened. Although theory and empirical work on the first part of the JD-R model, that is, between job resources and engagement, is relatively well-developed (e.g., Bakker \& Bal, 2010; Xanthopoulou, Bakker, Demerouti, \& Schaufeli, 2009), in comparison, there is little theoretical development and/or empirical work that have examined moderators in the subsequent stages of the JD-R model, that is, between work engagement and its outcomes. Although we used existing theories to inform our hypotheses, and some theory and empirical work suggests that psychological states, such as engagement, may interact with job resources (e.g., Hackman \& Oldham, 1976; Johns, Xie, \& Fang, 1992), our non-significant results may point researchers to focus on other resources (e.g., personal resources) that may amplify the relationship between engagement and absence. Alternatively, future research may examine whether for some types of jobs (e.g., professional and managerial), job resources are multiplicative, whereas for other types of jobs (e.g., manual), job resources and engagement act as substitutes for one another.

Additional noteworthy points of discussion stem from the additional analyses that we conducted for each moderation hypothesis. Specifically, we examined whether the points that represent high and low levels of engagement at high and low levels of the moderator were significantly different from one another (Dawson, in press). The results for trust and LMX lend strength to the argument that organisational trust and LMX compensate for lower levels of engagement. The results for MPS, however, paint a more complex picture.

A substantial number of highly engaged employees had higher rates of voluntary absence when jobs were high in motivating potential. Although this may seem counterintuitive, a plausible rationale is that some highly engaged employees with demanding and challenging jobs are more likely to need to take time off from work to recuperate. Macey and 
Schneider (2008) warned that there might be limits to the amount of engagement that is beneficial for employees and organisations. Halbesleben, Harvey and Bolino (2009) confirmed that too much engagement is detrimental to employees. They found that engagement is associated with higher levels of work interference with family because employees dedicate too much of their time to helping others at work.

The results also showed that at low levels of engagement, absenteeism did not vary with MPS. Although it is plausible that this is a consequence of the high correlation between engagement and MPS, we encourage future research to take a closer look at the relationship between lower levels of engagement and perceptions of job design. The classic Hackman and Oldham model of job design posits that a condition under which enriched jobs produce their intended motivational effect is when jobholders have a desire to grow and develop. The present results may lend weight to the argument that at lower levels of engagement, the effect of MPS may be contingent on a third resource, such as growth needs strength or a similar personal resource.

This finding also questions whether high levels of motivational job characteristics have uniformly positive outcomes. There have been some research findings, like ours, which suggests that very high levels of MPS may be detrimental to employees. For instance, research has revealed that high responsibility (French \& Caplan, 1974) and high mental and social demands (Schaubroeck \& Ganster, 1993) are associated with stress. Research has also found a curvilinear U-shaped relationship between job scope and emotional exhaustion, such that at very high levels of job scope, employees become increasingly emotionally exhausted (Xie \& Johns, 1995).

Our findings therefore call for a re-evaluation of whether job characteristics are best conceived of as a job resource and/or a job demand. In the case of job design, there may be an optimal level in which job characteristics act as a resource, but when the motivating potential 
score reaches a certain point, job characteristics may become a job demand, causing the jobholder to experience stress and ill health. This has implications for the study of employee absence which has tended to focus on the cause of absence as either due to ill health (i.e. can't attend work) or motivation (i.e. won't attend work), and suggests that different factors independently predict each (e.g., Schaufeli et al., 2009). Task characteristics may in fact predict both.

Future research should employ longitudinal, diary-study, and/or experimental designs to further investigate the possibility that very high levels of both engagement and MPS are detrimental for employees and organisations. For instance, researchers could follow employees over time to examine how changes in engagement and perceptions of job design influence important organisational outcomes such as absenteeism and performance. Field experiments may involve a 2 (engaging work-related task versus non-engaging work-related task) $\times 2$ (provided with a role with high motivating potential versus not provided with a role with high motivating potential) design. For instance, if a sample of engineering technicians was attained, half could be provided with an engaging task (e.g., constructing buildings) and the other half with a less engaging task (e.g., tallying petrol mileage to and from work sites). Each condition would then be provided with either very high levels of feedback from the job, or not. Dependent measures may include quality and quantity of performance, along with measures of wellbeing or emotional exhaustion, to tease out whether there are negative consequences for employees who have high levels of both engagement and motivational job design.

In summary, the present study contributes to the existing literature on both work engagement and absence. Although the work engagement literature has primarily conceptualised job resources as antecedents of work engagement (e.g., Bakker \& Demerouti, 2007), we examined the interaction between job resources and work engagement on absence. 
This is because Johns (1997) suggested that voluntary absence might best be predicted by interactions among psychological variables. Whether an interaction would take place between engagement and job resources on other outcomes, such as task performance, citizenship behaviours, or counterproductive work behaviours is a worthy avenue for future research. So too is research on the effect of other job resources to determine the extent to which other job resources are interchangeable with the ones tested in the present study. Although conservation of resources theory suggests that job resources tend to travel together in "resource caravans" (Hobfoll, 2011), future research has yet to confirm whether some job resources do or do not moderate the effect of engagement on relevant outcomes. The results of the present study hint that resources may not always be interchangeable with one another; MPS did not buffer the effect of lower levels of engagement on absence like organisational trust and LMX.

Our study also contributes to the absence literature by using a relatively under-utilised measure of voluntary absence, that is, the Bradford Factor. Future research should consider using the Bradford Factor as a measure of voluntary absence because it emphasises the number of absence spells, while not neglecting absence duration.

\section{Practical Implications}

The primary practical implication of the present study is to ensure that employees trust the organisation and have a high quality relationship with their leader. Regardless of whether these job resources lead to engagement, or act as its substitute, ensuring that these job resources are in place for employees is advantageous for organisations.

In order to engender organisational trust, employers should implement clearly defined structures, roles, and guidelines with regards to decision-making and employee conduct to provide direction about acceptable behaviour at work (Gillespie \& Dietz, 2009). Trust can also be heightened when the organisation emphasises inclusiveness, open communication, individuality, and encourages its managers to provide on-going feedback to employees 
(Whitener, Brodt, Korsgaard \& Werner, 1998). Employers may also wish to consider investing in corporate social responsibility initiatives. Such activities signal to employees that the organisation acts with moral concern for the wellbeing of its stakeholders (Aguilera, Rupp, Williams, \& Ganapathi, 2007) and is negatively related to absenteeism (ShapiraLishchinsky \& Rosenblatt, 2008).

Organisations should also focus on ensuring that leaders develop high quality LMX relationships with their employees. Mayfield and Mayfield (1998) suggested that the formation of a high quality LMX relationship begins at recruitment. At this stage, the leader should provide a realistic preview of the benefits and responsibilities of the relationship. Once hired, a leader should begin the LMX process through communicating mutual work expectations with employees and informing them of behaviours that will be rewarded. Research has established a number of leader behaviours that can improve LMX relationships, including leading by example, recognizing subordinates for their successes, consulting with employees on a variety of work-related matters, and delegating important tasks to employees (Yukl, O’Donnell, \& Taber, 2009). Organisations can also facilitate formal training programs that invite both leaders and followers, and focus on an explanation of the LMX process and outcomes, and LMX communication training (Mayfield \& Mayfield, 1998). Research shows that LMX relationships improve when leaders and members are trained accordingly (e.g., Scandura \& Graen, 1984).

This study also has practical implications for how HR managers use engagement scores from annual employee surveys. Many organisations today compute an engagement index to evaluate their people management practices. Practitioners should be cautioned against relying solely on such indices, as employee engagement scores alone may not tell the full story; even if engagement scores are relatively low, if employees are provided with 
sufficient job resources, their level of absenteeism may be similar to those who are engaged with their work.

A final implication of this study is a reminder to consider the manner in which absence is measured in organisations. There is some evidence from the practitioner literature that the use of Bradford Factor acts as a deterrent to employees who take leaves of absence for non-genuine reasons. A number of organisations have reported a reduction in absence when Bradford Factor are introduced, which may be due to the use of the system as a visible warning signal that voluntary absence is not tolerated by the organisation (IDS, 2007).

Although it is recommended that practitioners use the Bradford Factor as a measure of absence, it should not be used in isolation. Instead, practitioners should combine it with employee consultation. This is because not all employees with high Bradford scores are absent because of non-genuine reasons. For instance, an employee who has a child with a chronic illness may need to take a series of one-day absences during the year. This will lead to a relatively high Bradford score, which may trigger the organisation's absence review procedures. If the review is conducted with the initial assumption that the absences are illegitimate, then the employee may feel unfairly judged by the organisation, and subsequently may become less engaged. It is therefore important to suspend judgment until a formal meeting is held with the employee.

\section{Limitations}

Aside from the measure of absenteeism used in the current study, the independent and moderating variables were measured at the same time. While the study hypotheses are based on a strong theoretical foundation, alternative causal ordering is a possibility. Testing the proposed model using a longitudinal research design would help address this limitation. In addition, the sample used in the present study was drawn from one organisation in the United Kingdom, which may limit the generalisability of the findings. For instance, Lam, 
Schaubroeck and Aryee (2002) found that the negative relationship between perceptions of the work environment and absenteeism was stronger at lower levels of power distance. Likewise, it may be that our results are more pronounced in lower power distance cultures. Additionally, all variables aside from absenteeism were derived from self-report measures, raising concerns of common method variance. However, established recommendations for controlling for the influence of common method bias were followed, such as the use of established scales, guaranteed anonymity, and a clear explanation of procedures (Podsakoff, MacKenzie, Jeong-Yeon Lee, \& Podsakoff, 2003). In addition, the statistical analyses revealed that common method variance did not wholly explain the associations in the data, and the variables in the analyses were distinct from one another.

The use of the Bradford Factor as a measure of voluntary absence is not without its limitations. For instance, the weighting of frequency versus duration in the equation may not necessarily be accurate. Moreover, the Bradford Factor (like frequency and duration measures of absence) does not indicate why an employee was absent from work. Furthermore, an employee may be genuinely ill periodically for short periods of time due to chronic medical condition, such as migraines. Such an employee will have a high Bradford Factor, but it is not an indication of a lack of motivation.

An additional limitation of the present study is that we did not assess a mediator of the moderated relationships in order to conduct an empirical test of the theoretical explanation for our hypotheses. We encourage future research to measure positive emotions as a potential mediator in order to tease out the underlying processes of the moderating relationship between engagement and job resources on outcomes.

A final limitation is that little variance in absence was explained by the hypothesised models. However, the $\mathrm{R}^{2}$ statistics in the present study are commensurate with some prior research, notably Soane et al.’s (2013) study of the relationship between meaningfulness, 
wellbeing and engagement on absence duration. Given the complicated nature of identifying moderating relationships in field studies, even $1 \%$ of incremental variance explained by an interaction is a significant finding (Evans, 1985; McClelland \& Judd, 1993). In our study, the interaction term explained from $2 \%$ to $8 \%$ of incremental variance demonstrating the strength of the interactive effect of job resources and engagement on absence. Nonetheless, an expanded research model should be developed to contribute to a better understanding of the role of engagement in explaining absence.

\section{Conclusion}

The present study examined the moderating role of job resources on the relationship between engagement and voluntary absenteeism, as measured by the Bradford Factor. The results showed that organisational trust and a high quality LMX relationship moderated the relationship between engagement and voluntary absence, such that they buffered the negative relationship between engagement and absence. 


\section{References}

Aguilera, R. V., Rupp, D. E., Williams, C. A., \& Ganapathi, J. (2007). Putting the S back in corporate social responsibility: A multilevel theory of social change in organizations. Academy of Management Review, 32(3), 836-863.

Aiken, L. S., \& West, S. G. (1991). Multiple regression: Testing and interpreting interactions. Newbury Park: Sage.

Arbuckle, J. L. (2006). AMOS (version 7.0) [computer program]. Chicago: SPSS.

Bakker, A. B., \& Bal, P. M. (2010). Weekly work engagement and performance: A study among starting teachers. Journal of Occupational and Organizational Psychology, 83, 189-206.

Bakker, A. B., \& Demerouti, E. (2007). The job demands-resources model: State of the art. Journal of Managerial Psychology, 22(3), 309-328.

Bakker, A. B., Demerouti, E., de Boer, E., \& Schaufeli, W. B. (2003). Job demands and job resources as predictors of absence duration and frequency. Journal of Vocational Behavior, 62(2), 341-356.

Bakker, A. B., Hakanen, J. J., Demerouti, E., \& Xanthopoulou, D. (2007). Job resources boost work engagement, particularly when job demands are high. Journal of Educational Psychology, 99(2), 274-284.

Becker, T. E. (2005). Potential problems in the statistical control of variables in organizational research: A qualitative analysis with recommendations. Organizational Research Methods, $8,274-289$

Bentler, P. M. (1990). Comparative fit indexes in structural models. Psychological Bulletin, 107(2), 238-246

Bentler, P. M., \& Bonett, D. G. (1980). Significance tests and goodness-of-fit in the analysis of covariance structures. Psychological Bulletin, 88(3), 588-600. 
Blumberg, M., \& Pringle, C. D. (1982). The missing opportunity in organizational research: Some implications for a theory of work performance. The Academy of Management Review, 7(4), 560-569.

Brooke, Jr. P. P. (1986). Beyond the Steers and Rhodes model of employee attendance. The Academy of Management Review, 11(2), 345-361.

Browne, M. W., \& Cudeck, R. (1993). Alternative ways of assessing model fit. In K. A. Bollen, \& J. S. Long (Eds.), Testing structural equation models (pp. 136-162). Newbury Park: Sage.

Caplan, G. (1974). Support systems and community mental health. New York, NY: Behavioral Publications.

Chadwick-Jones, J. K., Nicholson, N., \& Brown, C. (1982). Social psychology of absenteeism. New York, NY: Praeger.

CIPD. (2010). Absence management. London, UK: Chartered Institute of Personnel Management.

Cohen, S., \& McKay, G. (1984). Social support, stress and the Buffering Hypothesis: A theoretical analysis. In A. Baum, S.E. Taylor, \& J.E. Singer (Eds.), Handbook of Psychology and Health (pp. 253-267). Hillsdale, NJ.

Colquitt, J. A., Scott, B. A., \& LePine, J. A. (2007). Trust, trustworthiness, and trust propensity: A meta-analytic test of their unique relationships with risk taking and job performance. Journal of Applied Psychology, 92(4), 909-927.

Conlin, M. (2007). Shirking hooky: The war on hooky. Business Week, http://www.businessweek.com/stories/2007-11-11/shirking-working-the-war-on-hooky

Cortina, J. M., Chen, G., \& Dunlap, W. P. (2001) Testing interaction effects in LISREL: Examination and illustration of available procedures. Organizational Research Methods, 4(4), 324-360. 
Csikszentmihalyi, M. (1990). Flow: The psychology of optimal experience. New York: Harper.

Darr, W., \& Johns, G. (2008). Work strain, health, and absenteeism: A meta-analysis. Journal of Occupational Health Psychology, 13(4), 293-318.

Dawson, J. F. (in press). Moderation in management research: What, why, when, and how. Journal of Business Psychology. DOI: 10.1007/s10869-013-9308-7

Dekkers-Sánchez, P. M., Hoving, J. L., Sluiter, J. K., \& Frings-Dresen, M. H. W. (2008). Factors associated with long-term sick leave in sick-listed employees: A systematic review. Occupational and Environmental Medicine, 65(3), 153-157.

Demerouti, E., Bouwman, K., \& Sanz-Vergel, A. I. (2011). Job resources buffer the impact of work-family conflict on absenteeism in female employees. Journal of Personnel Psychology, 10(4), 166-176.

Demerouti, E., Nachreiner, F., Baker, A. B., \& Schaufeli, W. B. (2001). The job demandsresources model of burnout. Journal of Applied Psychology, 86(3), 499-512.

Dienesch, R. M. \& Liden, R. C. (1986). Leader-member exchange model of leadership: A critique and further development. Academy of Management Review, 11(3), 618-634.

Dirks, K. T., \& Ferrin, D. L. (2001). The role of trust in organisational settings. Organization Science, 12(4), 450-467.

Durbin, J. \& Watson, G. S. (1951). Testing for serial correlation in least squares regression, II. Biometrika, 30, 159-178.

Edwards, J. R., \& Cable, D. M. (2009). The value of value congruence. Journal of Applied Psychology, 94(3), 654-677.

Evans, M. G. (1985) A Monte-Carlo study of the effects of correlated method variance in moderated multiple regression analysis. Organizational Behavior and Human Decision Processes 36(3), 305-323. 
Farrell, D., \& Stamm, C. (1988). Meta-analysis of the correlates of employee absence. Human Relations, 41(3), 211-227.

Field, A. (2013). Discovering statistics using IBM SPSS statistics (4 ${ }^{\text {th }}$ ed.) London: Sage.

Fredrickson, B. L. (1998). What good are positive emotions? Review of General Psychology, 2(3), 300-319.

Fredrickson, B. L. (2001). The role of positive emotions in positive psychology: The broadenand-build theory of positive emotions. American Psychologist, 56(3), 218-226.

Fredrickson, B. L., \& Branigan, C. (2005). Positive emotions broaden the scope of attention and thought-action repertoires. Cognition and Emotion, 19(3), 313-332.

French, J. R. P. Jr. \& Caplan, R. D. (1973). Organizational stress and individual strain. In A.J. Murrow (Ed.) The failure of success. New York: AMACOM (pp. 30-66).

Fried, Y., \& Ferris, G. R. (1987). The validity of the job characteristics model. A review and meta-analysis. Personnel Psychology, 40(2), 287-322.

Gillespie, N. \& Dietz, G. (2009). Trust repair after an organization-level failure. Academy of Management Review, 34(1), 127-145.

Gorgievski-Duijvesteijn, M. J., \& Hobfoll, S. E. (2008). Work can burn us out or fire us up: Conservation of resources in burnout and engagement. In J. R. B. Halbesleben (Ed.), Handbook of stress and burnout in healthcare (pp. 7-22). New York: Nova Science Publishers.

Graen, G. B., \& Scandura, T. A. (1987). Toward a psychology of dyadic organizing. Research in Organizational Behavior, 9, 175-208. 
Graen, G. B., \& Uhl-Bien, M. (1995). Relationship-based approach to leadership: Development of leader-member exchange (LMX) theory of leadership over 25 years: Applying a multilevel multi-domain perspective. The Leadership Quarterly, 6(2), 219-247.

Hackett, R. D., \& Guion, R. M. (1985). A reevaluation of the absenteeism-job satisfaction relationship. Organizational Behavior and Human Decision Processes, 35(3), 340-381.

Hackman, J. R., \& Oldham, G. R. (1975). Development of the job diagnostic survey. Journal of Applied Psychology, 60, 159-170.

Hackman, J. R., \& Oldham, G. R. (1976). Motivation through the design of work: Test of a theory. Organizational Behavior and Human Performance, 16(2), 250-279. doi: 10.1016/0030-5073(76)90016-7

Hair, J. F., Black, W. C., Babin, B. J., \& Anderson, R. E. 2009. Multivariate Data Analysis (7 ed.). New Jersey: Pearson Prentice Hall

Halbesleben, J. R. B., Harvey, J., \& Bolino, M. C. (2009). Too engaged? A conservation of resources view of the relationship between work engagement and work interference with family. Journal of Applied Psychology, 94(6), 1452-1465.

Hanisch, K. A. \& Hulin, C. L. (1991). General attitudes and organizational withdrawal: An evaluation of a causal model. Journal of Vocational Behavior, 39(1), 110-128

Harrison, D. \& Martocchio, J. (1998). Time for absenteeism: A 20-year review of origins, offshoots, and outcomes. Journal of Management, 24(3), 305-350.

Harvey, J., \& Nicholson, N. (1999). Minor illness as a legitimate reason for absence. Journal of Organizational Behavior, 20(6) 979-994.

Hobfoll, S. E. (1989). Conservation of resources: A new attempt at conceptualizing stress. American Psychologist, 44(3), 513-524. 
Hobfoll, S. E. (2011). Conservation of resource caravans and engaged settings. Journal of Occupational and Organizational Psychology, 84, 116-122.

Hu, L. \& Bentler, P. M. 1998. Fit indices in covariance structure modeling: Sensitivity to underparameterized model misspecification. Psychological Methods, 3(4): 424-453

Johns, G. (1997). Contemporary research on absence from work: Correlates, causes and consequences. International Review of Industrial and Organizational Psychology, 12, 115173.

Johns, G., Xie, J. L., \& Fang, Y. (1992). Mediating and moderating effects in job design. Journal of Management, 18(4), 657-676.

Kahn, W. A. (1990). Psychological conditions of personal engagement and disengagement at work. Academy of Management Journal, 33(4), 692-724.

Levine, H. (1960). Robust tests for equality of variances. In Olkin, I., Ghurye, S.G., Hoeffding, W., Madow, G. \& Mann, H.B. (Eds), Contributions to probability and statistics (pp. 278292). Stanford CA: Stanford University Press.

Macey, W., \& Schneider, B. (2008). The meaning of employee engagement. Industrial and Organisational Psychology, 1(1), 3-30.

Martocchio, J. J. (1989). Age-related differences in employee absenteeism: A meta-analysis. Psychology and Aging, 4(4), 409-414.

Mathieu, J. E., Tannenbaum, S. I., \& Salas, E. (1992). Influences of individual and situational characteristics on measures of training effectiveness. Academy of Management Journal, 35, 828-847.

Mayfield, J., \& Mayfield, M. (1998). Increasing worker outcomes by improving leader follower relations. The Journal of Leadership Studies, 5(1), 72-81. 
McClelland, G. H. \& Judd, C. M. (1993). Statistical difficulties of detecting interactions and moderator effects. Psychological Bulletin, 114(2), 376-390.

McEvily, B., Perrone, V., \& Zaheer, A. (2003). Trust as an organizing principle. Organization Science, 14(1), 91-103.

Miner, K. N., Settles, I. H., Pratt-Hyatt, J. S., \& Brady, C. C. (2012). Experiencing incivility in organisations: The buffering effects of emotional and organisational support. Journal of Applied Social Psychology, 42(2), 340-372. doi: 10.1111/j.1559-1816.2011.00891.x

Morgeson, F. P. \& Humphrey, S. E. (2006). The work design questionnaire (WDQ): Developing and validating a comprehensive measure for assessing job design and the nature of work. Journal of Applied Psychology, 91(6), 1321-1339.

Morris, J. H., Sherman, J. D., \& Mansfield, E. R. (1986). Failure to detect moderating effects with ordinary least squares-moderated multiple regression: Some reasons and a remedy. Psychological Bulletin, 99(2), 282-288.

Nicholson, N., \& Johns, G. (1985). The absence culture and the psychological contract: Who's in control of absence? Academy of Management Review, 10(3), 397407.

Podsakoff, P. M., MacKenzie, S. B., Jeong-Yeon Lee, \& Podsakoff, N. P. (2003). Common method biases in behavioral research: A critical review of the literature and recommended remedies. Journal of Applied Psychology, 88(5), 879.

Robinson, S. L. \& Rousseau, D. M. (1994). Violating the psychological contract: Not the exception but the norm. Journal of Organisational Behavior, 15(3), 245-259.

Rosenblatt, Z. \& Shirom, A. (2003). Predicting teacher absenteeism by personal background factors. Journal of Educational Administration, 43(2), 209-225.

Sagie, A. (1998). Employee absenteeism, organisational commitment, and job satisfaction: Another look. Journal of Vocational Behavior, 52(2), 156-171. 
Sagie, A., Birati, A., \& Tziner, A. (2002). Assessing the costs of behavioral and psychological withdrawal: A new model and an empirical illustration. Applied Psychology: An International Review, 51(1), 67-89.

Scandura, T. A., \& Graen, G. B. (1984). Moderating effects of initial leader-member exchange status on the effects of a leadership intervention. Journal of Applied Psychology, 69(3), 428436.

Schaubroeck J., \& Ganster, D. C. (1993). Chronic demands and responsivity to challenge. Journal of Applied Psychology, 78(1), 73-85.

Schaufeli, W. B., \& Bakker, A. B. (2004). Job demands, job resources, and their relationship with burnout and engagement: A multi-sample study. Journal of Organizational Behavior, 25, 293-315.

Schaufeli, W. B., Bakker, A. B., \& Van Rhenen, W. (2009). How changes in job demands and resources predict burnout, work engagement, and sickness absenteeism. Journal of Organisational Behavior, 30(7), 893-917.

Schaufeli, W. B., Salanova, M., Gonzalez-Roma, V., \& Bakker, A. B. (2002). The measurement of engagement and burnout: A two sample confirmatory factor analytic approach. Journal of Happiness Studies, 3, 71-92.

Scott, K. D., \& Taylor, G. S. (1985). An examination of conflicting findings on the relationship between job satisfaction and absenteeism: A meta-analysis. The Academy of Management Journal, 28(3), 599-612.

Shantz, A., Alfes, K., Truss, C., \& Soane, E. (2013). The role of employee engagement in the relationship between job design and task performance, citizenship and deviant behaviours. The International Journal of Human Resource Management. 
Shapira-Lishchinsky, O. \& Rosenblatt, Z. (2008). Perceptions of organizational ethics as predictors of work absence: A test of alternative absence measures. Journal of Business Ethics, 88, 717-734.

Soane, E., Shantz, A., Alfes, A., Truss, C., Rees, C., \& Gatenby, M. (2013). The association of meaningfulness, wellbeing and engagement with absenteeism: A moderated mediation model. Human Resource Management, 52(3), 441-456.

Stevens, J. P. (2002). Applied multivariate statistics for social sciences $\left(4^{\text {th }}\right.$ ed.). Hillsdale, NJ: Erlbaum.

Taylor, S. (2008). People Resourcing (4 ed.). London: CIPD

ten Brummelhuis, L. L., Bakker, A. B., \& Euwema, M. C. (2010). Is family-to-work interference related to co-workers' work outcomes? Journal of Vocational Behavior, 77, 461-469.

ten Brummelhuis, L L., ter Hoeven, C. L., Bakker, A.B., \& Peper, B. (2011). Breaking through the loss cycle of burnout: The role of motivation. Journal of Occupational and Organizational Psychology, 84, 268-287.

ten Brummelhuis, L. L., ter Hoeven, C. L., de Jong, M. D. T., \& Peper, B. (2013). Exploring the linkage between the home domain and absence from work: Health, motivation, or both? Journal of Organisational Behavior, 34(3), 273-290.

Towers Watson. (2012). Retrieved December/28, 2012, from http://www.towerswatson.com/canada-english/research/7731

VandenHeuvel, A. (1997). Absence because of family responsibilities: An examination of explanatory factors. Journal of Family and Economic Issues, 18(3), 273-297.

van Dierendonck, D., Le Blanc, P. M., van Breukelen, W. (2002). Supervisory behavior, reciprocity and subordinate absenteeism, Leadership \& Organization Development Journal, 23(2), 84-92. 
Wayne, S. J., Shore, L. M., \& Liden, R. C. (1997). Percieved organizational support and leadermember exchange: A social exchange perspective. Academy of Management Journal, 40(1), 82-111.

Whitener, E. M., Brodt, S. E., Korsgaard, M. A., \& Werner, J. M. (1998). Managers as initiators of trust: An exchange relationship framework for understanding managerial trustworthy behavior. Academy of Management Review, 23(3), 513-530.

Wollard, K. K. (2011). Quiet desperation: Another perspective on employee engagement. Advances in Developing Human Resources, 13(4), 526-537.

Wright, T. A. (2005). The role of happiness in organizational research: Past, present and future directions. In Perrewe, P.L. \& Ganster, D.C. (Eds.), Exploring interpersonal dynamics: Research in occupational stress and wellbeing, Vol 4, New York: Elsevier Science/JAI Press (pp. 221-264).

Xanthopoulou, D., Bakker, A. B., Dollard, M. F., Demerouti, E., Schaufeli, W. B., Taris, T. W., \& Schreurs, P. J. G. (2007). When do job demands particularly predict burnout? Journal of Managerial Psychology, 22(8), 766-786.

Xie, J. L. \& Johns, G. (1995). Job scope and stress: Can job scope be too high? Academy of Management Journal, 38(5), 1288-1309.

Yukl, G., O’Donnell, M., \& Taber, T. (2009). Influence of leader behaviors on the leadermember exchange relationship. Journal of Managerial Psychology, 26(4), 289-299. 
Tables and Figures

Table 1

Descriptive Statistics

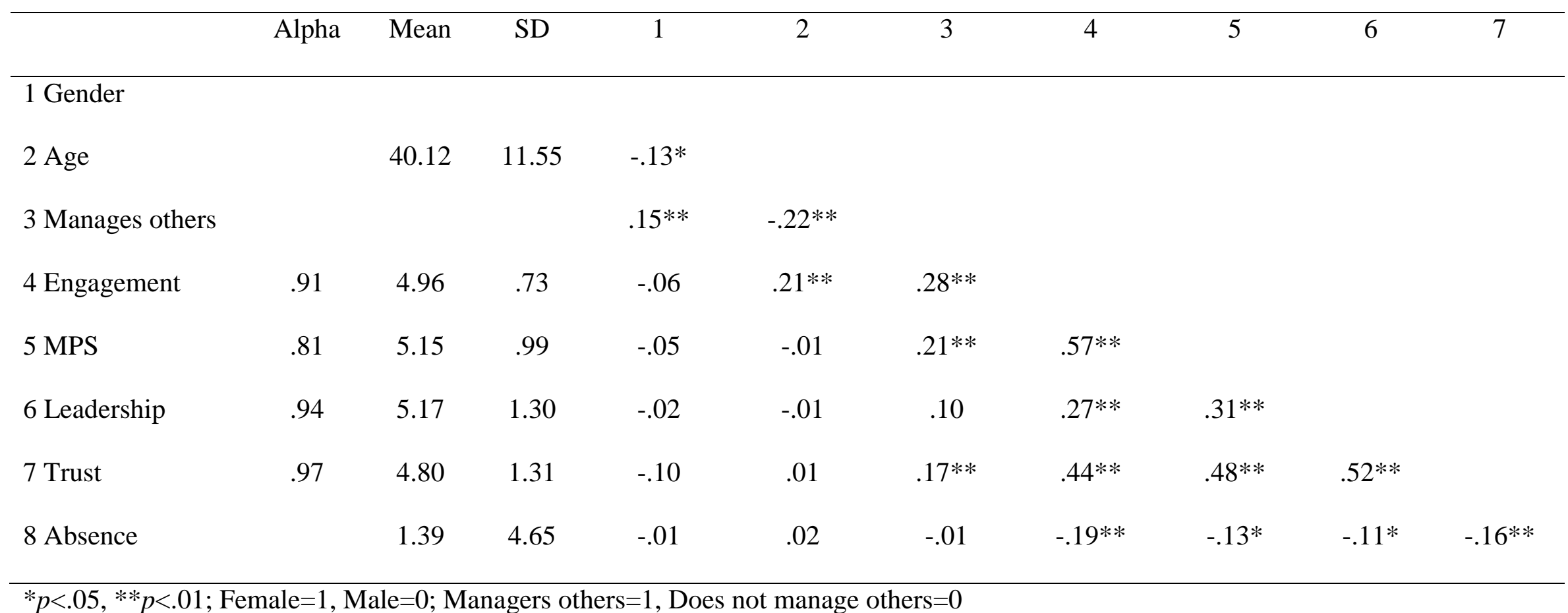


Table 2

Fit Statistics from Measurement Model Comparison

\begin{tabular}{|c|c|c|c|c|c|c|c|}
\hline Models & $\mathrm{X}^{2}(d f)$ & $C F I$ & $T L I$ & RMSEA & $S R M R$ & $\chi_{\text {diff }}^{2}$ & $d f_{\text {diff }}$ \\
\hline Full measurement model & $592(202)$ & .930 & .920 & .077 & .055 & & \\
\hline Model A ${ }^{\mathrm{a}}$ & $944(205)$ & .867 & .850 & .105 & .088 & 352 & $3 * * *$ \\
\hline Model B ${ }^{\mathrm{b}}$ & $1043(205)$ & .849 & .830 & .112 & .121 & 451 & $3 * * *$ \\
\hline Model $C^{c}$ & $698(205)$ & .911 & .900 & .086 & .065 & 106 & $3 * * *$ \\
\hline Model D ${ }^{d}$ & $1923(205)$ & .690 & .651 & .161 & .131 & 1331 & $3 * * *$ \\
\hline Model $\mathrm{E}^{\mathrm{e}}$ & 2214 (207) & .638 & .596 & .173 & .149 & 1622 & $5 * * *$ \\
\hline $\begin{array}{l}\text { Model F } \\
\text { (Harman's Single Factor Test) }\end{array}$ & $2479(208)$ & .590 & .545 & .184 & .155 & 1887 & $6 * * *$ \\
\hline
\end{tabular}

Notes: $* * * p<.001 ; X^{2}=$ chi-square discrepancy, $d f=$ degrees of freedom; CFI=Comparative Fit Index; TLI=Tucker-Lewis Coefficient; RMSEA=Root Mean Square Error of Approximation; SRMR= Standardised Root Mean Square Residual; $\chi_{\text {diff }}^{2}=$ difference in chi-square, $d f_{\text {diff }}=$ difference in degrees of freedom. All models are compared to the full measurement model.

${ }^{a}=$ Engagement and organisational trust combined into a single factor

$\mathrm{b}=$ Engagement and leadership combined into a single factor

${ }^{c}=$ Engagement and motivating potential score combined into a single factor

$\mathrm{d}=$ Organisational trust and leadership combined into a single factor

$\mathrm{e}=$ Organisational trust, leadership and motivating potential score combined into a single factor

$\mathrm{f}=$ All factors combined into a single factor 
Table 3

Hierarchical Moderated Regressions on Employee Absenteeism

\begin{tabular}{|c|c|c|c|c|c|c|c|c|}
\hline & & \multirow{2}{*}{$\begin{array}{c}{\text { Baseline } \text { Model }^{a}} \\
\beta(S E)\end{array}$} & \multicolumn{2}{|c|}{$\begin{array}{c}\text { Moderating Role of } \\
\text { Organisational Trust }\end{array}$} & \multicolumn{2}{|c|}{$\begin{array}{c}\text { Moderating Role of } \\
\text { Leadership }(L M X)\end{array}$} & \multicolumn{2}{|c|}{$\begin{array}{c}\text { Moderating Role of Job } \\
\text { Design (MPS) }\end{array}$} \\
\hline & & & $\beta(S E)$ & $\beta(S E)$ & $\beta(S E)$ & $\beta(S E)$ & $\beta(S E)$ & $\beta(S E)$ \\
\hline \multirow[t]{3}{*}{ Step 1} & Gender & $.01(.55)^{\mathrm{c}}$ & & & & & & \\
\hline & Age & $.02(.03)$ & & & & & & \\
\hline & Manager & $.01(.55)$ & & & & & & \\
\hline \multirow[t]{6}{*}{ Step 2} & Gender & & $.02(.57)$ & & $-.01(.57)$ & & $-.01(.57)$ & \\
\hline & Manager & & $.05(.58)$ & & $.05(.58)$ & & $.05(.59)$ & \\
\hline & Engagement & & $-.17(.32)^{*}$ & & $-.19(.30) * *$ & & $-.19(.35)^{*}$ & \\
\hline & Trust & & $-.10(.31)$ & & & & & \\
\hline & Leadership & & & & $-.07(.28)$ & & & \\
\hline & MPS & & & & & & $-.04(.34)$ & \\
\hline \multirow[t]{7}{*}{ Step 3} & Gender & & & $.01(.56)$ & & $-.02(.56)$ & & $.01(.55)$ \\
\hline & Age & & & $.04(.02)$ & & $.05(.02)$ & & $.04(.02)$ \\
\hline & Engagement & & & $-.15(.32)^{*}$ & & $-.19(.29) * *$ & & $-.18(.34)^{*}$ \\
\hline & Trust & & & $-.08(.31)$ & & $-.04(.28)$ & & $.06(.34)$ \\
\hline & Engage*Trust & & & $.13(.23)^{*}$ & & & & \\
\hline & Engage*LMX & & & & & $.15(.26)^{* * *}$ & & \\
\hline & Engage*MPS & & & & & & & $.28(.23)^{* * *}$ \\
\hline $\operatorname{Adj} R^{2}\left(\Delta^{d}\right)$ & & 0 & $.03 * *$ & $.05 *$ & $.03 * *$ & $.05 * *$ & $.02 * *$ & $.09 * *$ \\
\hline$F$ & & .06 & $2.84 * *$ & $3.22 * *$ & $2.60 *$ & $3.31 * *$ & $2.40 *$ & $5.56^{* *}$ \\
\hline
\end{tabular}

a The baseline model includes the control variables (gender, age and management responsibilities) only.

${ }^{\mathrm{b}}$ The first sub column reports the main effects of controls, engagement and organisational trust on absenteeism; the second column reports the moderated regression results ${ }^{\mathrm{c}} \mathrm{Standardised}$ regression coefficients (standard error)

Indicates whether $R^{2}$ was significantly improved from previous step 